\title{
EDUCACIÓN FÍSICA Y SALUD
}

\section{Hernán Felipe Prieto Bernar*}

Se nos pide hablar acerca de la interrelación entre la Educación Física y Salud. Quisiera desde ya dejar en claro que no pretendo en ninguna forma cuestionar las buenas intenciones, los valiosos esfuerzos, los plausibles proyectos, la encomiable dedicación, de todos aquellos que en una u otra forma luchan por aproximar de manera creadora estos dos conceptos, estas dos prácticas, estas dos instituciones.

Pero hoy, aquí, cerca a ustedes, quiero que se me permita, no ocuparme de planes y proyectos tendientes a tal fin, sino manifestar mis dudas, mis reservas, mis temores, que no alcanzan siquiera el rango de hipótesis, sino apenas el de preocupaciones.

Mis cavilaciones, lo reconozco desde el primer momento, no resistirían la más leve de sus objeciones, el más sencillo de sus argumentos, puesto que, ¿quién preferiría a la clara y límpida fotografía, un añoso y desastrado negativo? ¿Qué utilidad tiene entonces que haga públicas mis interrogaciones? Quizás, la de contribuir a fortalecer aún más sus convicciones y denodados esfuerzos.

Si lo que a continuación sigue suena tan asertivo, tan seguro, tan convencido, lo es, no por el contenido, sino por el tono. Igual que un niño eleva sus reclamos ante los seres que quiere: si hiere, lo hace no por que quiera, sino porque en el fondo de su corazón desea ser convencido de lo contrario.

Mi intervención el día de hoy, se limitará a preguntarse por el origen de éstos dos conceptos, prácticas e instituciones. De vez en cuando viene bien preguntarse por las bases de los edificios que con tanto esfuerzo construimos.

\section{Nos quieren sanos}

"Quiero una juventud fuerte y hermosa...así podré crear algo nuevo” Adolfo Hitler.

Sí, indudablemente nos quieren sanos, ningún otro siglo como éste nos ha querido tan sanos. Abra usted el periódico, escuche la radio, vea televisión, hojee una revista, vaya a una librería, contemple las vallas publicitarias, escuche a los maestros, los políticos, las amas de casa: la salud se ha convertido en una cosa de dominio público. Estar enfermo hace ya mucho tiempo dejó de ser un hecho privado (¿alguna vez lo fue?) Su enfermedad nos afecta, nos incumbe, nos atañe. Su salud nos interesa, es fuente de preocupación para nosotros: ¿Fuma? ¿Bebe? ¿Se droga? Eso nos preocupa. Eso nos afecta. Durante la época nazi ser judío era una enfermedad que por lo menos merecía una estrella amarilla en el saco y la reducción al ghetto. ..lo demás venía por añadidura. Hoy se prohíbe que se fume en espacios públicos o se reduce al fumador a micro-espacios concentracionarios: aislar reducir, controlar: al judío, al negro, al palestino, al colombiano,

\footnotetext{
* Profesor UPN. (Ponencia presentada en el Seminario Taller 'Colombia en Forma" organizado por la División de Educación Física y Formación Deportiva de Coldeportes: Sep. 1 a 5 de 1993).
} 
al fumador, al hombre con altos niveles de colesterol, al niño hiperkinético, a la mujer nerviosa, al disidente. Sí, definitivamente, nos quieren sanos. La enfermedad es ahora, también una desviación.

La vida, la "propia" vida, es una verdadera rareza hoy en día: nacemos en un hospital, morimos en una clínica, nos velan en una funeraria, nos dan un número en el cementerio. La vida se controla, la muerte se esconde. El gran sueño de Hitler: extender la educación a todos los niveles de la vida del hombre, sin dejar espacio, resquicio, grieta alguna se ha cumplido: la escuela, la fabrica, las asociaciones, los partidos, los clubes, las fundaciones... pasamos de una a otra de esas instituciones o nos "afilian" a varias: en todas ellas nuestra salud es su preocupación.

Las mismas empresas que en la segunda guerra mundial fabricaban el gas de cianuro para los campos de concentración son las que hoy hacen los ambientadores para el hogar moderno. La "señora bien" que arruga, molesta, su delicada naricita, ante el fumador que tiene en frente, es la misma que con su carro se "fuma" el equivalente diario de 200 cigarrillos. Las sociedades "desarrolladas" tan obsesivas de su ambiente y su ecología, son las que producen el $90 \%$ de desechos no bio-degradables en el mundo. Los vasos desechables en que tomamos nuestras bebidas para proteger nuestra salud irán a parar a las entrañas de las ballenas del mar. Mientras una porción de la humanidad puja, suda, hace dieta, se convierte en anoréxica, con tal de mantenerse en forma, la inmensa mayoría de la población mundial se hunde en el hambre y la miseria.

Sí, verdaderamente nos quieren sanos. ¿Para qué? ¿Para nuestro propio bien? Si así fuera, la gallina y el cerdo deberían llamar "benefactores" a los que los vacunan y engordan para el matadero. ¿Con propósitos humanitarios? Si así fuera, los judíos que pasaban bajo el arco de los campos de concentración leyendo en sus vallas "el trabajo os hará libres" deberían bendecir a sus asesinos.

En 1994 Theodor Adorno escribe la primera sección de su "Mínima Moralia" bajo el epígrafe de Ferdinand Kümberger "La vida no vive". El número 35 de sus pensamientos lleva por título "La salud para la muerte". Sí, nos quieren sanos para una muerte. No hay duda. Para una muerte que comienza para no ser nuestra. Es la muerte que los "sanos" nos inoculan pacientemente, día a día, meticulosamente: nos matan con salud. Nos morimos de nuestras enfermedades, morimos de su salud y su salud se llama: Muerte. Muertos en vida, zombis productivos y eficaces, útiles y formales, disciplinados y controlados, marchamos cantando hacia la muerte, es decir, su salud:

"Las libidinosas actividades exigidas del individuo que se comporta conforme a su salud de cuerpo y alma, son de tal índole que solo pueden ser ejecutadas en virtud de la más profunda mutilación, de una sublimación de la castración en los extrovertidos, en comparación con la cual el viejo tema de la identificación con el padre es el juego de niños en el que aquella fue ensayada" (Adorno, Op. cit.).

Mutilados, castrados, ¿De qué? ¿De qué están enfermos los sanos? "La enfermedad de los sanos puede diagnosticarse únicamente de manera objetiva: como una desproporción entre sus modos de vida racional y la posible determinación racional de sus vidas" (ibídem).

Pagamos nuestra salud de normales al precio de renunciar a la determinación racional de nuestras vidas: 90-60-90 para los reinados de belleza, examen de ICFES en la escuela, lo mismo: "Sobre la base de la salud imperante se asienta la muerte" (ibídem). 
¿Y la salud Pública? No siempre es grato recordar su origen: el 6 de Mayo de 1793, la Revolución francesa conforma el "comité de salud pública" que será el aparato privilegiado del terror y la "santa guillotina". "Seamos terribles para evitar que lo sea el pueblo" (Dantón). "...Se ha de establecer la libertad por la violencia, y ha llegado el momento de organizar momentáneamente el despotismo de la libertad para aplastar el despotismo de los reyes" (Marat). "Esto puede parecer duro, pero lo que aún es más duro para un patriota es que desde hace dos años 100.000 hombres han sido degollados por traición y por debilidad; es la debilidad para los traidores la que nos pierde". (Robespierre).

Cuando la salud se hace pública, de dominio público, de "interés público", razones son las que sobran, vengan de donde vengan para instaurar las degollinas. Se practica la sangría a los enfermos congestionados, se hace sangrar la sociedad congestionada. ¿Cuánta sangre se hace necesaria? Tratándose de las sociedades nunca es suficiente para... restablecer el Imperio o el III Reich. Hay algo peor que la enfermedad de los enfermos y es la salud de los sanos: jay de aquel que no quiera sanar!

La "Enciclopedia" había ya definido como "la primera de las necesidades del hombre" a la salud. Villerme a comienzos del siglo XIX trae a la mirada clínica el concepto de "población", verdadero cruce de caminos entre la investigación biológica y la economía política, que junto con la Revolución Industrial y la jornada laboral de 8 horas, cambiaron las perspectivas del cuerpo y la salud. Se hacía necesario intensificar la explotación de los trabajadores durante dicha jornada de tal forma que no reventaran en sus puestos de trabajo. Verdaderamente nos quieren sanos: en la fábrica, en el campo de batalla, en la escuela, en el hogar. Nuestra salud ya nos incumbe, es "asunto de todos

¿Exagero? Veamos un poco el otro concepto: Educación Física. Philippe Ariés, uno de los más grandes investigadores franceses en historia de las mentalidades escribe:

"Durante el siglo XV III encontramos en la familia ...otro elemento nuevo: el interés por la higiene y la salud física. Los moralistas y educadores del siglo XVII no ignoraban el cuidado del cuerpo. Se cuidaba a los enfermos con abnegación (Si bien con grandes precauciones para descubrir a los que simulaban), mas el único interés por el cuerpo de aquellos que gozaban de buena salud era de orden moral: un cuerpo mal fortalecido propendía a la molicie, a la pereza, a la concupiscencia, a todos los vicios (p:186).

Así las cosas, nuestro concepto de salud, que creemos, error fatal, común a todas las épocas y a todas las culturas, no tiene más de 200 años: si a una persona hasta el siglo XVII se le inquiría por su salud, ésta escudriñaba entonces las profundidades de su alma, de sus costumbres, de sus pensamientos. Si le hacemos la misma pregunta a un hombre de nuestro tiempo, nos hablará de sus electroencefalogramas, de sus electrocardiogramas, exhibirá orgulloso las pruebas de rendimiento tísico, los índices de su colesterol, etc. Retomemos a Ariés:

'Los médicos del siglo XVIII inventaron a partir de los antiguos "juegos del ejercicio", de la gimnasia latina de los jesuitas, una técnica nueva de la higiene del cuerpo: la cultura física ... A finales del siglo XVIII, los juegos dc ejercicio recibieron otra justificación, patriótica esta vez: preparaban a la guerra. Todo el inundo se dio cuenta de los servicios que la educación física podía prestar a la instrucción militar. Era la época en que el adiestramento del soldado se tornaba una técnica casi erudita, la época también en que brotaban los nacionalismos modernos. Se estableció un parentesco entre los juegos 
educativos de los jesuitas, la gimnasia de los médicos, la instrucción de los soldados y las necesidades del patriotismo" (Ariés: 128-9).

Tales son los orígenes de la Educación Física: jesuitas, médicos y militares, con sus saberes y sus prácticas a partir del siglo XVIII la conformaron y fijaron sus propósitos: combatir los vicios, servir a la guerra.

Así decía uno de los primeros textos fundacionales de la educación física: "Gimnástica de la juventud o Tratado elemental de los juegos de ejercicios considerados por su utilidad física y moral" de Duvivier y Jauffret:

"Comprometidos por anticipado en la defensa común, por la naturaleza y el espíritu de nuestra constitución, Nuestros hijos son soldados antes de que nazcan” (Op. cit. 129).

Soldados antes de nacer.. ¿¿Qué había pasado? Ni más ni menos que una terrible mutación del poder descrita sabiamente por Foucault: una mutación en las relaciones entre la vida y la muerte. El siglo XVIII asiste al paso de la teoría clásica de la soberanía (esencialmente un "derecho de espada" cuyo lema sería "hacer morir o dejar vivir") hacia una sociedad de normalización propia de nuestros días. Aquel siglo ve nacer dos tecnologías - "que han entrado en escena con cierto desface cronológico y que se han superpuesto" - del poder: una tecnología disciplinaria sobre el cuerpo y una tecnología reguladora sobre las poblaciones que articuladas "ortogonalmente" permitirán modificar el lema de poder. Si antes, el poder soberano, era un poder de "hacer morir o dejar vivir", ahora, el enunciado típico del poder será "poder de hacer vivir y dejar morir". A partir del siglo XVIII el poder se ejerce cada vez más en el vector del "hacer vivir". Si decía que "nos quieren sanos" era precisamente por esto: se trata a partir del siglo XVIII de "hacer vivir". La educación física se inscribe en el proceso de re-acomodamiento de las técnicas disciplinarias tendientes a optimizar la vida, extrayendo y maximizando sabiamente las fuerzas del cuerpo. Si decía que la salud se hace "pública" entendía con esto la vectorización de la salud en el campo de las técnicas reguladoras de la población. Cuerpos dóciles y útiles de un lado, poblaciones "sanamente" reguladas del otro.

Surgirán entonces: una "anatomía política del cuerpo humano" y sus disciplinas, entre ellas, una educación física centrada en el aumento y cualificación de las aptitudes (hasta los discursos modernos en tomo al alto rendimiento), en el arrancamiento y aprovechamiento de las fuerzas del cuerpo (temas modernos de la eficiencia máxima), de su utilidad y docilidad (temas de la formación de hábitos y rutinas hasta el del entrenamiento controlado y permanente); pero también y a la par, una "biopolltica de la población", con sus problemas de proliferación, tasas de nacimiento y mortalidad, duración y calidad de vida. En fin, una verdadera administración de los cuerpos y una gestión calculadora de la vida, sobre las que Foucault alcanzó a trazar sus mapas y heredamos el compromiso de completarlos.

Se me dirá: ¿pretende entonces usted, acabar con la Educación Física, socavar las preocupaciones por la salud pública? Nada más tonto, todo lo contrario, pretendía con este brevísimo recorrido demarcar la tarea que nos queda:

1) Recordar que los conceptos que creemos obvios tienen una historia.

2) Que esa historia está bien lejos de ser inobjetable y desinteresada.

3) Y que, finalmente, nos corresponde luchar, más allá de las proclamaciones bienintencionadas, pero a veces ciegas a los movimientos oscuros que yacen bajo las claras aguas de la ingenuidad, en el plano de la salud por el ejercicio de la vida contra sus 
formas de dominación y control, y en el plano de la educación física, por rehacer nuestros cuerpos contra su conformación a las exigencias de la producción, la política y la guerra.

En general una lucha por una vida "higiénica", no en el sentido peligrosamente ascéptico que le hemos dado a esa palabra, sino en el lejano sentido que tuvo ese vocablo hace miles de años en el indo-europeo: Higiene, del indoeuropeo: su-gwiyes-ya , proveniente de los radicales: su-: bueno, bien y de gwiyes: vivir. Higiene ="vivir bien". Y "vivir bien", debería significar, no que otros nos vivan (propio de los animales domésticos) sino que nosotros cada día nos ejercitemos en vivir bien. Ya lo decía Aristóteles, los animales viven, solo el hombre vive bien. Creo que es aquí, donde una preocupación por la salud, depurada de sus larvas reguladoras, y una problematización de la educación física, liberada del lastre de sus penosos orígenes, tengan mucho que decirnos.

Al terminar la lectura de mi ponencia se me hicieron dos preguntas sobre las relaciones cuerpo-mente y sobre lo que entendía por "vivir bien". Considero pertinente incluir las respuestas que di en aquella oportunidad por cuanto permiten aclarar y ahondar en unos puntos de mi intervención.

El problema de las relaciones cuerpo-mente es un problema típicamente occidental, quizás comience con el Fedón de Platón y su muy "particular" lectura del concepto de "mente" en Anaxágoras y no terminará de serlo mientras occidente se empeñe en seguir exhibiendo orgullosamente su famoso "hombre integral". Pero es completamente desconocido para un Dogon del África central, para un esquimal, para un chino o un hindú, o para nuestro hermano mayor de la Sierra Nevada, de la misma manera que para un griego anterior a Platón. Es precisamente por ello que no podemos caer en la trampa de enunciar una norma común del "vivir bien". Todo lo contrario, de lo que se trata es de hacer proliferar las opciones entorno al vivir bien. Cuando me muestran orgullosamente el ario cuerpo musculoso de occidente como modelo del vivir bien, miro hacia Oriente y me encuentro con el risueñamente rollizo cuerpo de Buda —nada apropiado para comerciales de alimentos dietéticos_-, miro hacia el ventrudo y palmípedo cuerpo de Sócrates, miro hacia los enjutos y maravillosos cuerpos de nuestros chamanes de la Sierra Nevada y del Amazonas. ¿Se imaginan ustedes llevándoles nuestro evangelio "sano", profundamente preocupados por la salud de las narices, pulmones, intestinos, por el mambeo de la coca o el uso del yagé? Por favor entendamos que si nosotros nos preocupamos por tener rosados pulmones, otros se preocupan más bien por tener "rosada" su comunicación con la divinidad-y entiendo la terrible enseñanza de Foucault - "el poder es cada vez menos el derecho de hacer morir, es cada vez más, el derecho de intervenir para hacer vivir, de intervenir sobre la manera de vivir". Dejemos la normalización a los poderes, nuestra tarea es bien otra, consiste en aquello que los amantes de la norma han denominado: "herejía", ignorando su hermoso origen griego. Hairetikós en griego significa aquel que es capaz de escoger, de tomar decisiones por sí mismo y no por otro. Dejemos el dogma, la ortodoxia y la normalización a todos aquellos que están interesados en domesticar, regular y controlar. Admiremos al niño que con pantaloneta se esfuerza en los cien metros planos, pero defendamos la opción preciosa del sudoroso niño que juega "risueño" a las escondidas. Cautivémonos ante el esplendor del atleta de alto rendimiento que se enfrenta más allá de la programación controlada a la violencia y la muerte; pero defendamos al joven abandonado a la hermosa tarea de contemplar la evolución de las nubes en un suave prado junto a la mujer que ama; miremos con atención al anciano que se ejercita, para mi gusto por ejemplo preferiría el taichi; pero sólida- ricémonos con la exquisita pareja de ancianos que enfundados en sus gabardinas, salen a caminar, por el simple placer de caminar, cogidos de la mano, en un atardecer cualquiera, nimbados por el: "dolce far fiente". 
Bibliografía:

1)ADORNO, Theodor W, Mínima Moralia, Ed. Monte Avila, 1975.

2)ARIES, Philippe, EL niño y lo vida familiar en el Antiguo Régimen, Taurus, 1989.

3)FOUCAULT., Michael: Historia de la sexualidad. Vol I: la voluntad de saber, Ed. Siglo XXI, 1977, pag. 163 y ss. Hacer vivir y dejar morir: la guerra como racismo. En: Revista: Fin de siglo, dic. 1991, \#1. p. 19 y ss, 